\title{
THE OPERATIONAL PARAMETERS EFFECT ON PHOTOCATALYTIC DEGRADATION OF DIAZINON USING CARBON AND NITROGEN MODIFIED TiO
}

\author{
K. Khoiriah ${ }^{1}$, S. Safni ${ }^{1, *}$, S. Syukri ${ }^{1}$, and J. Gunlazuardi ${ }^{2}$ \\ Department of Chemistry, Faculty of Mathematics and Natural Sciences, Andalas University, \\ Padang 25163, Indonesia. \\ ${ }^{2}$ Department of Chemistry, Faculty of Mathematics and Sciences, University of Indonesia, \\ Depok 16424, Indonesia. \\ *E-mail: safni@sci.unand.ac.id
}

\begin{abstract}
Diazinon is one of the most active compounds containing in commercial pesticides used for agriculture application. The photocatalytic degradation of commercial emulsion diazinon using nanoparticles photocatalyst $\mathrm{C}, \mathrm{N}-\mathrm{codoped} \mathrm{TiO}_{2}$ under UV irradiation was investigated. The operational parameters, i.e., the modified titania, catalyst dose, initial $\mathrm{pH}$, the concentration of diazinon, $\mathrm{H}_{2} \mathrm{O}_{2}$, and humic acid as an additive were examined. Under optimal parameters, the diazinon with initial concentration $18 \mathrm{mg} \mathrm{L}^{-1}$ at $\mathrm{pH} 6$ in the presence of $12 \mathrm{mg} \mathrm{C,N-codoped} \mathrm{TiO}_{2}$ catalyst can be degraded $76 \%$ after 180 minutes irradiation. Whereas the mineralization of diazinon reached $37 \%$ as analyzed by total organic carbon analyzer (TOC). The additive compounds containing diazinon commercial give no effect under the photocatalysis process.
\end{abstract}

Keywords: C,N-codoped $\mathrm{TiO}_{2}$, Diazinon, Photocatalysis, Mineralization

(c) RASĀYAN. All rights reserved

\section{INTRODUCTION}

Diazinon is an organophosphate pesticide extensively used as pest control in plantation country such as Indonesia. ${ }^{1}$ It is effective in an application for various kinds of cultivations such as horticultural plants, tobacco, rice, corn, fruit trees, sugarcane, and palm. ${ }^{2}$ These activities cause the diazinon residues concentration to increase in the environment. On the other hand, this organic compound is a highly toxic pesticide, nonspecific target, low persistence in the environment ${ }^{3}$, immunotoxic ${ }^{4}$, cytotoxic and genotoxic ${ }^{5-7}$ and categorized as moderately hazardous class II by the World Health Organization (WHO). Thus, the removal and reduction of diazinon concentration from the water represent an emerging environmental concern. The pure diazinon is mostly used in the investigation rather than commercial ones. However, the application is more in the form of commercial insecticide emulsion which contains the organic solvent, additive, and impurities for its solubility and stability in water. The presence of those organic compounds mentioned above in emulsion can cause additional complications such as possible reactions among them and their degradation byproducts in the photocatalytic process. ${ }^{1}$

Titania $\left(\mathrm{TiO}_{2}\right)$ is one of the selected photocatalyst used for organic pollutant degradation such as diazinon into $\mathrm{H}_{2} \mathrm{O}$ and $\mathrm{CO}_{2}$ because it is effective, stable against photo-corrosion, photoactive, and environmentfriendly ${ }^{8-10}$ However, the wide bandgap $(3.2 \mathrm{eV})$ of titania causes limitations in an extensive application under photocatalysis. Recently, modified $\mathrm{TiO}_{2}$ by codoping with non-metals $(\mathrm{C}, \mathrm{N}$, and $\mathrm{S})$ is one of the most efficient techniques. Its product will have higher photocatalytic activity and special characteristics compared with single doped $\mathrm{TiO}_{2}$. Synergistic effect of dopants results in narrow bandgaps (redshift) leading to higher photoresponse and photocatalytic activity under high energy source (UV-light) ${ }^{11}$ and low energy (visible-light). ${ }^{12,13}$ Nanoparticles of $\mathrm{C}, \mathrm{N}$-codoped $\mathrm{TiO}_{2}$ have been synthesized by using water solvent and reported single doped and un-doped ones. ${ }^{14,15}$

Rasayan J. Chem., 13(3), 1919-1925(2020)

http://dx.doi.org/10.31788/ RJC.2020.1335743 
RASĀYAN J. Chem.

Vol. 13 | No. 3 |1919-1925| July - September | 2020

The pure diazinon was degraded by the photocatalysis process using modified titania such as $\mathrm{FeFNS}-\mathrm{TiO}_{2}{ }^{16}$, $\mathrm{N}$-doped $\mathrm{TiO}_{2}{ }^{17}, \mathrm{Fe}$-doped $\mathrm{TiO}_{2}{ }^{18}$. While the commercial form of diazinon was studied using $\mathrm{TiO}_{2} \mathrm{PC}-102^{19}$. This present work investigates the effect of the operational parameters on photocatalytic degradation of formulation diazinon using $\mathrm{C}, \mathrm{N}$-codoped $\mathrm{TiO}_{2}$ as a photocatalyst. The parameters are; effects of modified titania, catalyst dose, initial $\mathrm{pH}$, the concentration of diazinon, $\mathrm{H}_{2} \mathrm{O}_{2}$, and humic acid as an additive.

\section{EXPERIMENTAL}

\section{Material and Methods}

A commercial emulsion containing $600 \mathrm{~g} \mathrm{~L}^{-1}$ diazinon, (Code Name Diazinon $600 \mathrm{EC}$ ) was used as organic pollutant insecticide in water. A diazinon standard (CAS No. 333-41-5) was purchased from SigmaAldrich. Ethanol 95\%, a solvent for diazinon stock solution was purchased from Sigma-Aldrich. Preparation steps and full characterization of the $\mathrm{C}, \mathrm{N}$-codoped $\mathrm{TiO}_{2}$ nanoparticles were conducted according to the previous publication ${ }^{14}$.

The change of diazinon concentration was analyzed by and DR600 ${ }^{\mathrm{TM}} \mathrm{UV}$-vis spectrophotometer (Hach, USA). The total organic carbon of degraded diazinon was analyzed by the TOC analyzer (Shimadzu, Serial No. H571049). The $\mathrm{pH}$ of diazinon was measured by using Prolab $2000 \mathrm{pH}$ meter (SCHOTT Instruments $\mathrm{GmbH}$, Germany). The UV light intensity was measured by IL1400A Radiometer/Photometer (International Light Technologies, Inc).

\section{General Procedure}

Photocatalytic reactions were performed in a batch system under 13 Watt UV lamps irradiation (Germicidal CEG13 Base BFC $11004, \lambda=254 \mathrm{~nm}$ ). The solution of diazinon with concentration $18 \mathrm{mg} \mathrm{L}^{-1}$ was added by photocatalyst (10 at.\% C,N-codoped $\mathrm{TiO}_{2}$ after calcination at $500{ }^{\circ} \mathrm{C}$ ) and irradiated under $1.7 \mathrm{~mW} \mathrm{~cm} \mathrm{~cm}^{-2}$ UV-lamp. During the photocatalytic reaction, the optimal C,N-codoped $\mathrm{TiO}_{2}$ dose was set at experiments with different diazinon concentrations, initial diazinon $\mathrm{pH}, \mathrm{H}_{2} \mathrm{O}_{2}$, and humic acid addition were conducted to investigate their effects on the degradation efficiencies of diazinon. Aliquots were sampled every interval times $\left(30,60,120\right.$, and 180 minutes) and diazinon residue was detected by a DR600 ${ }^{\mathrm{TM}}$ UV-vis spectrophotometer at $247 \mathrm{~nm}$. The degraded diazinon solution under optimal condition was also measured by SCL-10A VP HPLC (Shimadzu) equipped with Poroshell 120 SB-Aq 2.7 (4.6 x $150 \mathrm{~mm}$ ) column, using 80/20 (methanol/water, v/v), volume injection and flow rates were $20 \mu \mathrm{L}$ and $0.5 \mathrm{~mL} \mathrm{~min}^{-1}$, respectively. The mineralization percentage of degraded diazinon was analyzed by using a TOC analyzer (Shimadzu, Serial No. H571049).

\section{The Effect of Modified Titania on Diazinon Degradation \\ RESULTS AND DISCUSSION}

Figure-1 represents the effect of carbon and nitrogen as dopant on the degradation of diazinon. Photocatalysis also conducted using single doped $\mathrm{TiO}_{2}$ carbon, nitrogen, and un-doped as a control. As seen in Fig.-3 diazinon efficiency is greater under photocatalysis using carbon and nitrogen modified titania than single doped. This result can be elucidated by the small band gap and high crystalline of $\mathrm{C}, \mathrm{N}$-codoped $\mathrm{TiO}_{2}$ than $\mathrm{C}$-doped $\mathrm{TiO}_{2}, \mathrm{~N}$-doped $\mathrm{TiO}_{2}$ and un-doped $\mathrm{TiO}_{2}$ with the bandgap is $2.87 \mathrm{eV}, 2.97 \mathrm{eV}, 3.02 \mathrm{eV}$, and $3.09 \mathrm{eV}$ respectively as reported in our previous research. ${ }^{14}$ Carbon and nitrogen give synergy effect on modified titania with having high crystallinity and low bandgap. Three opinions regard to the mechanism of modified $\mathrm{TiO}_{2}$ by doping using non-metals:

1. The dopant incorporates into the $\mathrm{TiO}_{2}$ crystalline lattice and alters the structure of $\mathrm{TiO}_{2}$ electronic band which leads the level of the dopant above the $\mathrm{O} 2 \mathrm{p}$ valence band and the bandgap of $\mathrm{TiO}_{2}$ becomes narrower. Some $\mathrm{Ti}^{4+}$ are converted to be $\mathrm{Ti}^{3+}$ by non-metal dopant through charge compensation and generated $\mathrm{Ti}^{3+}$ forms donor energy below the conduction band of $\mathrm{TiO}_{2}$.

2. The co-doped carbon produces a photosensitizer by forming carbonaceous species on the surface of $\mathrm{TiO}_{2}$.

3. Nitrogen dopant substitutes the oxygen site of $\mathrm{TiO}_{2}$ and forms the impurity energy level above the valence band ${ }^{12}$.

The Effect of Catalyst Dose on Diazinon Degradation

Catalyst dose is one of the most factor influences photocatalysis degradations. To optimize C,N-codoped $\mathrm{TiO}_{2}$ dose, the catalyst with an amount $(0,6,12,18$, and $24 \mathrm{mg})$ was added into the diazinon solution while 
RASĀYAN J. Chem.

Vol. 13 | No. 3 |1919-1925| July - September | 2020

another parameter is keeping constant. The experiment was also carried out under UV photolysis without catalyst addition as a control. Diazinon was removed $11 \%$ for $180 \mathrm{~min}$ irradiation times indicating the direct photolysis is not effective. As presented in Fig.-2 the efficiency increases significantly in the presence of 6-18 mg catalyst and decreases at amount $24 \mathrm{mg}$. The improvement in degradation at higher photocatalyst concentration can be explained by increasing the catalyst providing a higher active site and more photons adsorbed on catalyst surface for the photocatalytic reaction which increased in the oxidative species formation. Further increase in $\mathrm{TiO}_{2}$ concentration at $24 \mathrm{mg}$ addition, however, gives a negative effect. The exceeded optimal catalyst dose causes increasing turbidity, lower light penetration, and resulting agglomeration causes difficulty in the suspension homogenous form and lowering the number of active sites. ${ }^{20}$ Thus, the chosen catalyst as an optimal condition for the degradation process was $12 \mathrm{mg}$.

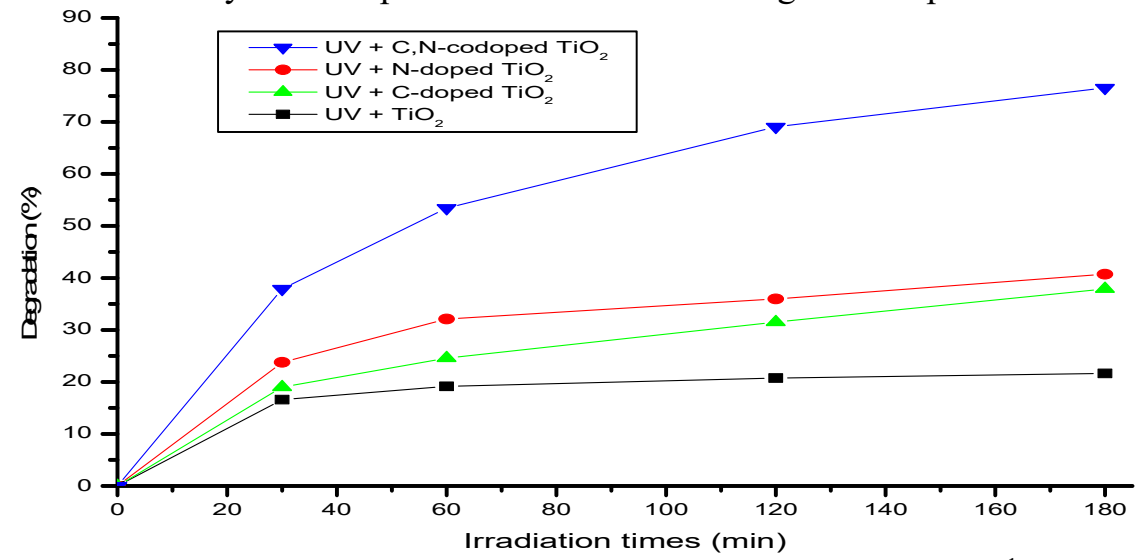

Fig.-1: The Effect of Doping Titania on Photocatalysis of Diazinon [Diazinon $=18 \mathrm{mg} \mathrm{L}^{-1}$, Catalyst $=12 \mathrm{mg}, \mathrm{t}=0$ 180 min, using $\mathrm{TiO}_{2}$, N-Doped $\mathrm{TiO}_{2}, \mathrm{C}$-Doped $\mathrm{TiO}_{2}$ and $\mathrm{C}, \mathrm{N}$-codoped $\left.\mathrm{TiO}_{2}\right]$

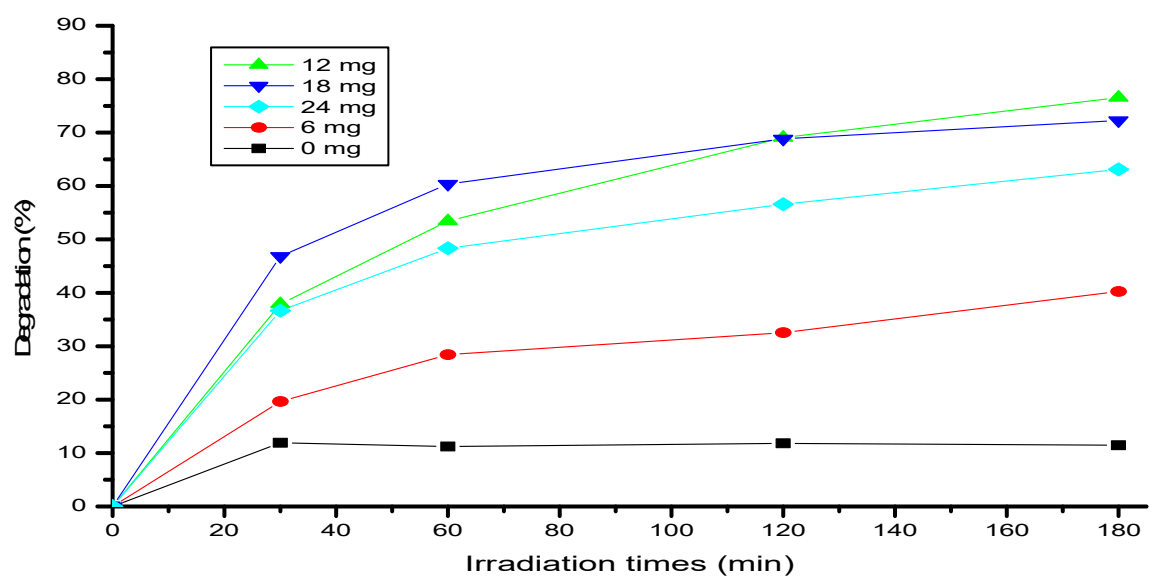

Fig.-2: The Effect of Catalyst Dose on Photocatalysis of Diazinon Using C,N-codoped $\mathrm{TiO}_{2}$ [Diazinon $=18 \mathrm{mg} \mathrm{L}^{-1}$, Catalyst $=0,6,12,18$ and $24 \mathrm{mg}, \mathrm{t}=0-180 \mathrm{~min}]$

\section{The Effect of Initial pH on Diazinon Degradation}

The effect of $\mathrm{pH}$ on the photocatalysis degradation of diazinon using $12 \mathrm{mg} \mathrm{C,N-codoped} \mathrm{TiO}_{2}$ was investigated at $\mathrm{pH} 3,5,6,7$, and 9 for $180 \mathrm{~min}$ irradiation. The results are shown in Fig. 3. As observed the optimal diazinon degradation was achieved at $\mathrm{pH}$ 6. It is reported that the $\mathrm{pH}_{\mathrm{zpc}}$ of nano-titania is at range 6.3-6.9. ${ }^{21}$ The titania surface will be positive at lower the $\mathrm{pH}_{\mathrm{zpc}}$ and negative at higher the $\mathrm{pH}_{\mathrm{zpc}}$. On the other hand, the $\mathrm{pKa}$ of diazinon is 2.6 which is negatively charged above $\mathrm{pH} 2.6$. Low diazinon degradation at higher $\mathrm{pH}$ is caused by the negatively charged of nano-titania catalyst preventing the negatively charged diazinon and hydroxide anion to adsorp in catalyst surface. Conversely, there is an electrostatic attraction between positive diazinon and catalyst in acidic conditions leading to a low degradation of diazinon. Therefore, the optimal condition is found at $\mathrm{pKa}$ diazinon $<\mathrm{pH}<\mathrm{pH}_{\mathrm{zpc}}$ catalyst. 
RASĀYAN J. Chem.

Vol. 13 | No. 3 |1919-1925| July - September | 2020

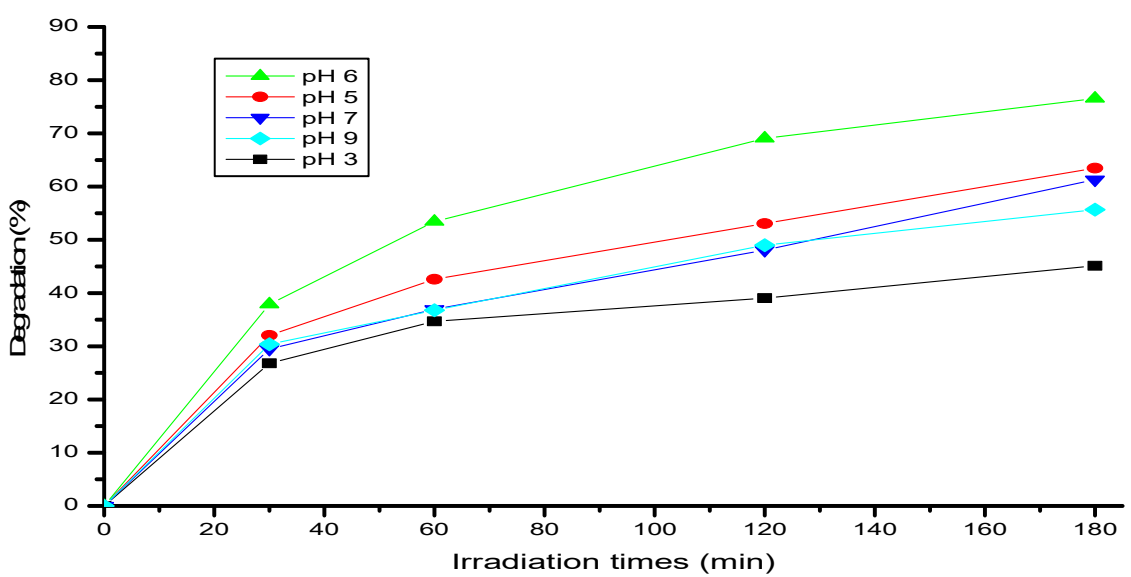

Fig.-3:The Effect of Initial $\mathrm{pH}$ on Photocatalysis of Diazinon Using C,N-codoped $\mathrm{TiO}_{2}\left[\right.$ Diazinon $=18 \mathrm{mg} \mathrm{L}^{-1}$, Catalyst $=12 \mathrm{mg}, \mathrm{pH}=3,5,6,7$, and $9 ; \mathrm{t}=0-180 \mathrm{~min}]$

\section{The Effect of Initial Concentration on Diazinon Degradation}

To investigate the effect of the initial concentration of diazinon under photocatalysis degradation, four different concentrations $\left(9,18,36\right.$ and $\left.54 \mathrm{mg} \mathrm{L}^{-1}\right)$ were selected. The reason for the chosen range of concentrations because of uncontrolled pesticides in the application for improving crop yielding by farmers in developing countries such as Indonesia. ${ }^{18,22}$ As shown in Fig.-4 the diazinon degradation increases by increasing the diazinon concentration over $18 \mathrm{mg} \mathrm{L}^{-1}$ followed by a decline pattern. The possible reason for decreasing photocatalytic degradation at a higher initial concentration of diazinon is more reactant molecules adsorbed on the catalyst surface which block active sites of the catalyst ${ }^{23}$. Another reason is at a higher concentration of diazinon generates higher intermediate that adsorbs, blocks, and deactivates the active sites of the catalyst. ${ }^{21}$

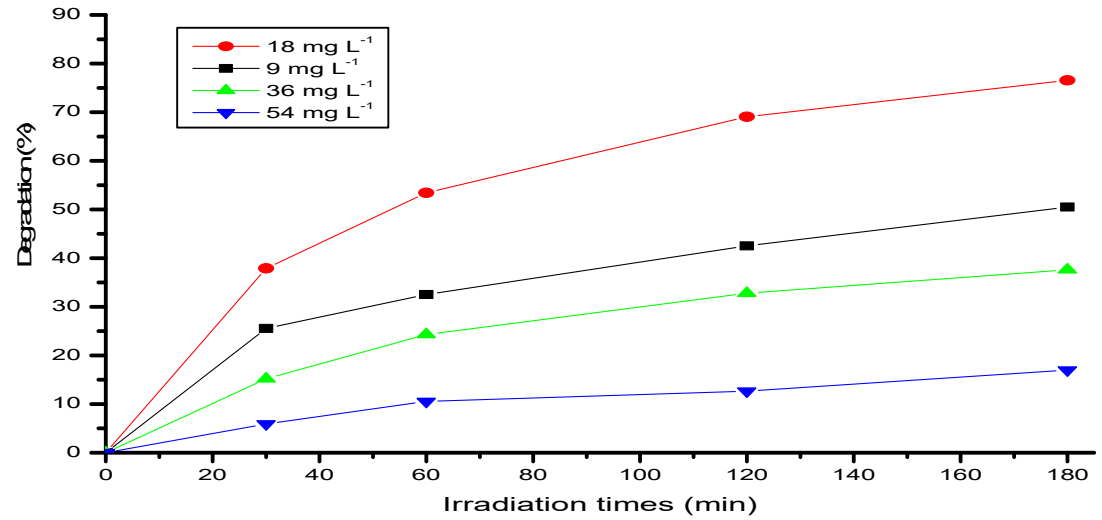

Fig.-4: The Effect of Initial Concentration on Photocatalysis of Diazinon [Diazinon $=9,18,36$, and $54 \mathrm{mg} \mathrm{L}^{-1}$, Catalyst $=12 \mathrm{mg} ; \mathrm{t}=0-180 \mathrm{~min}]$

\section{The Effect of $\mathrm{H}_{2} \mathrm{O}_{2}$ Addition on Diazinon Degradation}

The effect of $\mathrm{H}_{2} \mathrm{O}_{2}$ addition on diazinon degradation efficiency was examined at a series of hydrogen peroxide concentrations in range $0 \mathrm{mmol} \mathrm{L}-1-0.5 \mathrm{mmol} \mathrm{L}^{-1}$ as exhibited in Table 1 . The $\mathrm{H}_{2} \mathrm{O}_{2}$ addition gives a positive effect on the diazinon degradation at 30-60 minutes photocatalysis. The degradation efficiency decreases with increasing initial $\mathrm{H}_{2} \mathrm{O}_{2}$ concentration and the optimal concentration is found at $0.25 \mathrm{mmol} \mathrm{L}-1 \mathrm{H}_{2} \mathrm{O}_{2}$ addition. The diazinon degradation is $37.91 \%$ without $\mathrm{H}_{2} \mathrm{O}_{2}$ and increases to be $51.85 \%$ at $0.25 \mathrm{mmol} \mathrm{L}^{-1} \mathrm{H}_{2} \mathrm{O}_{2}$ addition. However, the addition of $0.5 \mathrm{mmol} \mathrm{L}^{-1} \mathrm{H}_{2} \mathrm{O}_{2}$ causes the descent of diazinon degradation to be $35.77 \%$. The presence of $\mathrm{H}_{2} \mathrm{O}_{2}$ at low concentration on the photocatalytic system could be an option electron acceptor to oxygen which inhibits the recombination process ${ }^{24,25}$. Also, $\mathrm{H}_{2} \mathrm{O}_{2}$ is can be as an additional free radical source through direct photolysis of $\mathrm{H}_{2} \mathrm{O}_{2}$ by UV-light as shown ${ }^{26}$. Those reactions would improve the efficiency of diazinon degradation. While $\mathrm{H}_{2} \mathrm{O}_{2}$ may act as a powerful 
RASĀYAN J. Chem.

Vol. 13 | No. 3 |1919-1925| July - September | 2020

scavenger of $\mathrm{HO} \bullet$ and hole-less effective on $\mathrm{HO}_{2}$ production at overdose addition on photocatalytic system leading to the reduction of diazinon degradation. ${ }^{27}$

Table-1: The Effect of $\mathrm{H}_{2} \mathrm{O}_{2}$ Addition on Photocatalysis of Diazinon

\begin{tabular}{c|c|c|c|c}
\hline \multirow{2}{*}{$\begin{array}{c}\text { Irradiation } \\
\text { Times (min) }\end{array}$} & \multicolumn{4}{|c}{ Diazinon Degradation on $\mathrm{H}_{2} \mathrm{O}_{2}$ Addition (\%) } \\
\cline { 2 - 5 } & $0 \mathrm{mmol} \mathrm{L}^{-1}$ & $0.125 \mathrm{mmol} \mathrm{L}^{-1}$ & $0.25 \mathrm{mmol} \mathrm{L}^{-1}$ & $0.50 \mathrm{mmol} \mathrm{L}^{-1}$ \\
\hline 30 & 37.91 & 51.851 & 35.769 & 48.589 \\
\hline 60 & 53.426 & 55.452 & 41.618 & 55.789 \\
\hline 120 & 69.057 & 69.033 & 45.419 & 61.531 \\
\hline 180 & 76.552 & 75.823 & 49.610 & 65.617 \\
\hline
\end{tabular}

\section{The Effect of Humic Acid Addition on Diazinon Degradation}

The effect of humic acid is important to be studied as its occurrence in natural water is in range 0.03-30 $\mathrm{mgCL}{ }^{-1} .^{28}$ The effect of humic acid effect on diazinon degradation was investigated at concentrations of 0 $18 \mathrm{mg} \mathrm{L}^{1}$. The diazinon removal decreases from $76.55 \%$ to be $29.41 \%$ in the presence of humic acid at concentration 3-18 $\mathrm{mg} \mathrm{L}^{-1}$. This decline could be attributed to the occupied catalyst surface by humic acid blocking the active sites for the access of diazinon. ${ }^{26,27}$ Besides, humic acid can be an optical filter as it has strong absorbance at 190 to $800 \mathrm{~nm}$ and competitively absorbs light and photons. ${ }^{28}$

\section{HPLC Analysis and Mineralization of Diazinon}

Figure-5 reports the HPLC chromatogram of diazinon solution before and after degradation for 180 minutes recorded at $247 \mathrm{~nm}$. There are three peaks detected; at retention time $3.7 \mathrm{~min}, 4.7 \mathrm{~min}$, and $5.3 \mathrm{~min}$ in the chromatogram of the initial solution. The first two peaks can be attributed to the organic solvent in the commercial diazinon emulsion. ${ }^{1}$ The intensity of those peaks keeps constant as increasing irradiation times, suggesting there is no degradation of those compounds. At the same time, the peak of diazinon at $t_{\mathrm{R}}=5.3$ min decreases in prolonging irradiation time, indicating the reduction and degradation of diazinon. As shown in Fig.-5b, the process produces a new peak at $t_{\mathrm{R}}=3.3 \mathrm{~min}$ and its intensity raises with decreasing diazinon concentration in longer photocatalysis. This result suggests that the photocatalysis process may transform diazinon and forms a new compound as degradation products. This compound peak appears at shorter retention times than that the diazinon, implying that the generated intermediate is smaller molecular weight and less polarity than that of diazinon. ${ }^{1}$

Figure- $5 \mathrm{c}$ shows that the degradation and mineralization degree of diazinon increase as the reaction time increased with efficiency $76 \%$ and $37 \%$, respectively. The amount of degraded diazinon is higher than that of the mineralized. This much difference indicated that the degradation processes produced transient organic intermediates on the photocatalysis system caused un-complete mineralization. ${ }^{29}$ This result is confirmed by the HPLC analysis that found a diazinon intermediate during photocatalytic degradation. When the titania catalyst was irradiated by photon, its electron will excite from valence band to conduction band which generates electron-hole. The reaction of oxygen and water with the generated electron-hole will form the strong oxidative hydroxyl radical. The radical and hole oxidize the organic pollutant to be $\mathrm{CO}_{2}$, $\mathrm{H}_{2} \mathrm{O}$, and some intermediates. ${ }^{26,30,31}$

\begin{tabular}{|c|c|c|c|c|}
\hline \multirow{2}{*}{$\begin{array}{c}\text { Irradiation } \\
\text { Times (min) }\end{array}$} & \multicolumn{4}{|c|}{ Diazinon Degradation on Humic Acid Addition (\%) } \\
\hline & $0 \mathrm{mg} \mathrm{L}^{-1}$ & $3 \mathrm{mg} \mathrm{L}^{-1}$ & $9 \mathrm{mg} \mathrm{L}^{-1}$ & $18 \mathrm{mg} \mathrm{L}^{-1}$ \\
\hline 30 & 37.91 & 36.83 & 34.07 & 6.794 \\
\hline 60 & 53.42 & 51.06 & 42.75 & 16.029 \\
\hline 120 & 69.057 & 54.98 & 52.27 & 29.405 \\
\hline 180 & 76.552 & 75.823 & 49.610 & 65.618 \\
\hline
\end{tabular}

The degradation of commercial diazinon emulsion using $\mathrm{C}, \mathrm{N}$-codoped $\mathrm{TiO}_{2}$ catalyst under UV-light irradiation was investigated. The diazinon degradation efficiency was strongly influenced by modified titania, catalyst dose, initial $\mathrm{pH}$, the concentration of diazinon, $\mathrm{H}_{2} \mathrm{O}_{2}$, and humic acid addition. The addition of $0.25 \mathrm{mmol} \mathrm{L}^{-1} \mathrm{H}_{2} \mathrm{O}_{2}$ improves diazinon efficiency at 30-60 minutes photocatalysis. While the presence of humic acid on the system decreases diazinon degradation. Photocatalysis of $18 \mathrm{mg} \mathrm{L}^{-1}$ diazinon at $\mathrm{pH} 6$ 
RASĀYAN J. Chem.

Vol. 13 | No. 3 |1919-1925| July - September | 2020

in the addition of $12 \mathrm{mg} \mathrm{C,N-codoped} \mathrm{TiO}_{2}$ catalyst can be degraded $76 \%$ and mineralized $37 \%$ after 180 minutes irradiation. The additive compounds containing diazinon commercial give no effect under the photocatalytic process.

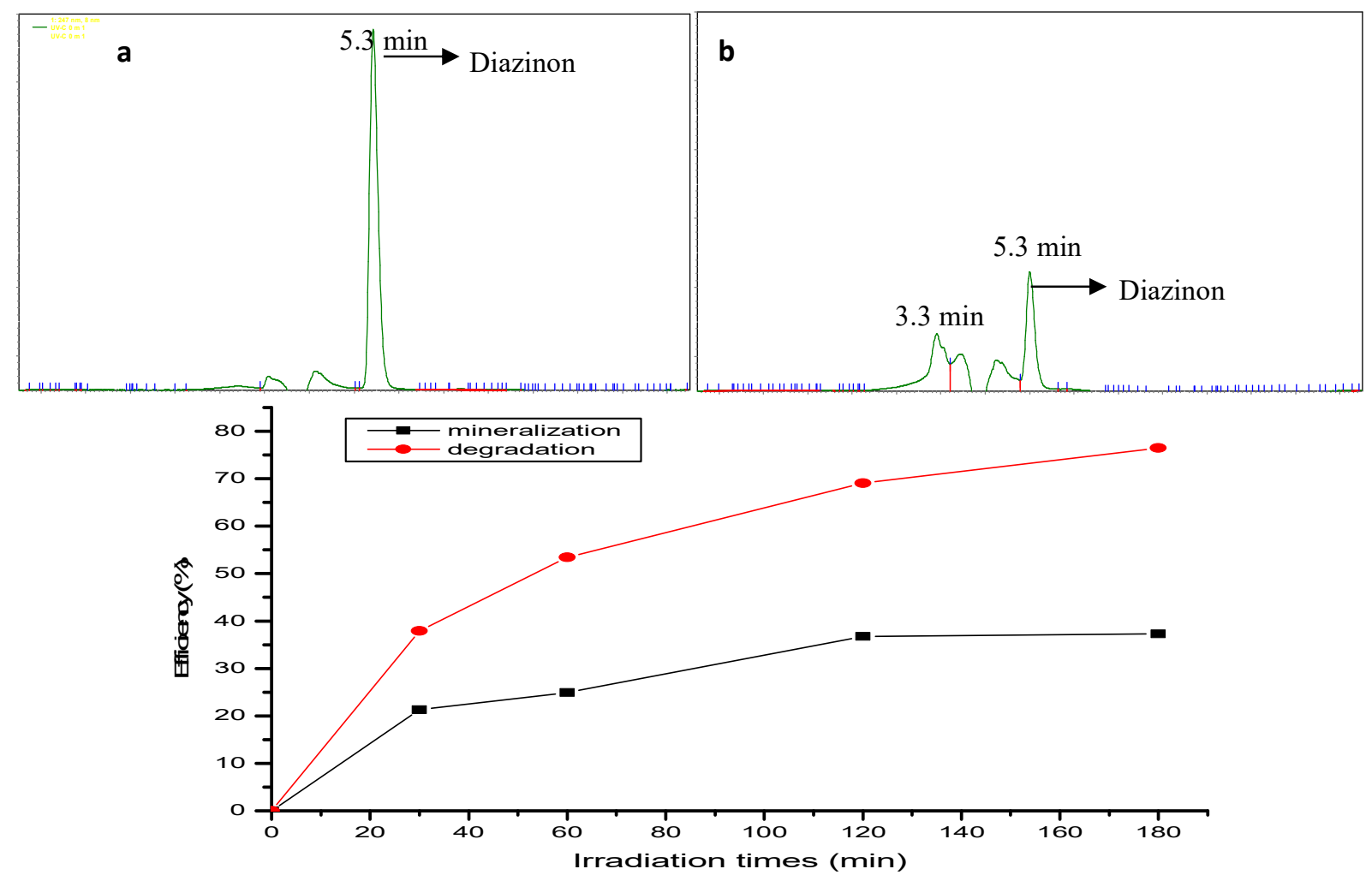

Fig.-5: Chromatogram of Diazinon (a) Before and (b) After Photocatalysis for $180 \mathrm{~min}$ (c) Mineralization Efficiency of Diazinon after 180 min Photocatalysis

\section{ACKNOWLEDGMENT}

Authors would like to thank the Ministry of Research, Technology, and Higher Education of Indonesia for financial support in this research through to the education of a master degree leading to the doctoral program for excellent graduates (PMDSU) (Grant number.059/SP2H/ LT/DRPM/IV/2018).

\section{REFERENCES}

1. K. Dai, T. Peng, H. Chen, J. Liu, and A. L. Zan, Environmental Science Technology, 43, 1540(2009), DOI: $10.1021 / \mathrm{es} 802724 \mathrm{qCCC}: \$ 40.75$

2. C. Tomlin, The Pesticide Manual: A World Compendium., 12th ed. British Crop Protection Council, Farnham, Surrey, UK (2000).

3. M. Čolović, D. Krstić, S. Petrović, A. Leskovac, G. Joksić, J. Savić, M. Franko, P. Trebše and V. Vasić, Toxicology Letters, 193(1), 9(2010), DOI:10.1016/j.toxlet.2009.11.022

4. E. Z. Neishabouria, Z. M. Hassan, E. Azizi and S. N. Ostad, Toxicology, 196(3), 173(2004), DOI:10.1016/j.tox.2003.08.012

5. F. D. G. Muranli, M. Kanev and K. Ozdemir, Arhiv za Higijenu rada i toksikologiju, 66(2), 153(2015), DOI:10.1515/aiht-2015-66-2584

6. A. B. Harchegani, A. Rahmani, E. Tahmasbpour, H. B. Kabootaraki, H. Rostami and A. Shahriary, Toxicology and industrial health, 34(9), 653(2018), DOI:10.1177/0748233718778665

7. L. Ezzi, Z. Haouas, I. B. Salah, A. Sakly, I. Grissa, S. Chakroun, E. Kerkeni, M. Hassine, M. Mehdi, and H. B. Cheikh, Environmental Science and Pollution Research International ,23(11), 11163(2016), DOI:10.1007/s11356-016-6314-0

8. G. S. Mital and T. Manoj, Chinese Science Bulletin, 56(16), 1639(2011), DOI:10.1007/s11434-0114476-1 
9. A. F. Caliman, C. Teodosiu and I. Balasanian, Environmental Engineering and Management Journal 1(2), 187(2002).

10. B. d. S. Guimarães, A. A. Bernardes, G. M. Salcedo, S. S. Caldas, M. B. Jorge, A. Bianchini, S. I. Wolke and E. G. Primel, Journal Brazillian Chemical Society, 27(12), 2256(2016), DOI: 10.5935/0103-5053.20160118

11. D. Dolat, N. Quici, E. Kusiak-Nejman, A. W. Morawski and G. Li Puma, Applied Catalysis B: Environmental, 115-116, 81(2012), DOI:10.1016/j.apcatb.2011.12.007

12. S. M. El-Sheikh, T. M. Khedr, AmerHakki, A. A. I. Ismail, W. A. Badawy, and D. W. Bahnemann, Separation and Purification Technology, 173, 258(2017), DOI:10.1016/j.seppur.2016.09.034

13. K. Khoiriah, D. V. Wellia, J. Gunlazuardi and S. Safni, Indonesian Journal of Chemistry, 20(3), 587 (2020), DOI:10.22146/ijc.43982

14. D. V. Wellia, D. Fitria and Safni, The Journal of Pure and Applied Chemistry Research, 7(1), 26(2018), DOI:10.21776/ub.jpacr.2018.007.01.373

15. Q. C. Xu, D. V. Wellia, S. Yan, D. W. Liao, T. M. Lim, and T. T. Y. Tan, Journal of Hazardous Materials, 188(1-3), 172(2011), DOI:10.1016/j.jhazmat.2011.01.088

16. H. Hossaini, G. Moussavi, and M. Farrokhi, Water Research 59, 130(2014), DOI:10.1016/j.watres.2014.04.009

17. A. Salarian, Z. Hami, N. Mirzaie, S. M. Mohseni, A. Asadi, H. Bahrami, M. Vosoughi, A. Alinejad, and M. Zare, Journal of Molecular Liquids, 220, 183(2016), DOI:10.1016/j.molliq.2016.04.060

18. S. Tabasideh, A. Maleki, B. Shahmoradi, E. Ghahremani, and G. McKay, Separation and Purification Technology 189, 186(2017), DOI:10.1016/j.seppur.2017.07.065

19. L. O. A. N. Ramadhan, and Amiruddin, Jurnal Ilmu Dasar, 14(1), 23(2013).

20. S. J. Jafari, G. Moussavi, and H. Hossaini, Desalination and Water Treatment, 57(8), 3782(2014), DOI: $10.1080 / 19443994.2014 .987171$

21. R. R. Kalantary, Y. D. Shahamat, M. Farzadkia, A. Esrafili and H. Asgharnia, Desalination and Water Treatment, 55(2), 555(2014), DOI:10.1080/19443994.2014.928795

22. T. Joko, S. Anggoro, H. R. Sunoko, and S. Rachmawati, Applied and Environmental Soil Science, 2017, 1-7 (2017), DOI:10.1155/2017/5896191

23. S. R. Taffarel, M. A. Lansarin, and C. C. Morob, Journal of Brazilian Chemical Society, 22(10), 1872 (2011).

24. C. C. Wong and W. Chu, Environmental Science Technology, 37(10), 2310(2003), DOI: 10.1021/es020898n

25. S. Ahmed, M. G. Rasul, R. Brown, and M. A. Hashib, Journal of Environmental Management, 92(3), 311(2011), DOI:10.1016/j.jenvman.2010.08.028

26. A. Jonidi-Jafari, M. Gholami, M. Farzadkia, A. Esrafili, and M. Shirzad-Siboni, Separation Science and Technology, 52(15), 2395(2017), DOI:10.1016/j.jtice.2014.12.020

27. M. Shirzad-Siboni, A. Jonidi-Jafari, M. Farzadkia, A. Esrafili, and M. Gholami, Journal of Environmental Management, 186(Pt 1), 1(2017), DOI:10.1016/j.jenvman.2016.10.049

28. C. Wang, L. Zhu, M. Wei, P. Chen, and G. Shan, Water Research, 46, 845(2012), DOI:10.1016/j.watres.2011.11.057

29. M. Sanchez, M. J. Rivero, and I. Ortiz, Applied Catalysis B: Environmental, 101(3-4), 515(2011), DOI: $10.1016 /$ j.apcatb.2010.10.023

30. D. Syafei, S. Sugiarti, N. Darmawan, and M. Khotib, Indonesian Journal of Chemistry, 17(1), 37(2017), DOI: $10.22146 /$ ijc. 23615

31. J. Gandhi, R. Dangi and S. Bhardwaj, Rasayan Journal of Chemistry, 1(3), 567(2008).

[RJC-5753/2020] 